\title{
Geochemical Properties of Peat Soil in Sarawak - A Review
}

\author{
Teong Ing Tong ${ }^{1,}$, and Felix, Ngee Leh Ling ${ }^{1, b}$ \\ ${ }^{1}$ Faculty of Civil and Env. Eng., Universiti Tun Hussein Onn Malaysia (UTHM), Malaysia \\ a teongingtong@gmail.com, ${ }^{b}$ felix@uthm.edu.my
}

\begin{abstract}
Keywords: Geochemical properties, Peat soil, Organic matter, Organic soil, Engineering properties
\end{abstract}

\begin{abstract}
In geotechnical field, peat soil is defined as soil which is formed by accumulation of purely one hundred percent organic matter and which the distinction between soil and vegetative accumulation is not clear. The main objectives of this review paper are to summarize and compare the geochemical properties of peat soil in different districts of Sarawak. Case studies that have been chosen covered central of Sarawak up to the North of Sarawak. Geochemical properties of peat soil that being observed are $\mathrm{pH}$, total carbon, organic matter, bulk density and the total nitrogen. Geochemical properties are found to be governed by the types of material inside the soil and also strongly correlated with the engineering properties of soil. Notably showed that the types of organic matter, namely fibre and/or humidified organic inside the soil will influence the soil porosity. The findings of the studies showed that geochemical properties of the peat soil in different districts of Sarawak is site dependent and could be affected by the different land use or land activities. The differences in land use and land activities affected the bulk density, $\mathrm{pH}$ and types of organic matter in the soil. The result indicated that peat soil land in different district can categorized as acidic soil because of the $\mathrm{pH}$ range is between 3.3-3.75. For the bulk density, the lowest value is recorded at the Dalat sago plantation site, which is $0.14 \mathrm{~g} / \mathrm{cm}^{3}$. For the value of the total carbon, peat soil from the Laogan Bunut National Park is the lowest, $47.6 \%$. Furthermore, total carbon is related to the soil organic matter, coincidentally the value of soil organic matter in Miri found to be the lowest which is $74.59 \%$. Result for the total nitrogen, there are little difference between the district. Range of the total nitrogen is from $0.9 \%$ to $2.4 \%$, Sibu site is getting the lowest value in this case.
\end{abstract}

\section{Introduction}

Over the last decade, Sarawak has undergone rapid development with the aim to reach the 2020 vision as high income country. A wide area was developed for the improvement of economy including the peat soil areas. Peat land in Malaysia is reported around 2.5 million hectares [1]. Sarawak has the largest peat area with $16,500 \mathrm{~km}^{2}$ and the peat deposits in $89 \%$ of these areas are more than $1 \mathrm{~m}$ in depth [2]. In Sarawak, most of the peat soil deposits are located at the delta and stretching inland along the riverine of the Samarahan-Sadong, Lupar-Saribas, Rajang, Baram and Limbang river system. Peat is described as naturally occurring, highly organic substance which derived primarily from plant materials [3]. Generally, peat soils are found to be high moisture content, high acidity and low strength. However, different types of forest will influence the biophysical and chemical properties [4]. In fact, types of forest determined the type of peat deposit formed. The forest types in Sarawak can be broadly into four types which are Mixed peat swamp forest, Alan Bunga, Alan Batu and Padang Alan forest. Besides it, human activities could also affect the chemical and physical properties of the peat soil [5].

Soil is made up of the heterogeneous mixture of the gases, solid, and liquid. Soil solid phrase is mixture of inorganic and organic matter which have different chemical composition. In this solid phrase, inorganic and organic will have different particles with the different sizes, shapes and the component. For the different types of the minerals, there will have different types of the crystallite. Different shape or formation of the crystal will giving different physical charateristic, such as the hardness, pore sizes of the soil. Besides that, different chemical components will have different combination, this will leading to different structures and giving the different chemical reactivates. So there are importance that to determine out the geochemical in soil to an understanding practical 
environmental problems [6]. The geochemical properties of four districts of Sarawak were reviewed in this paper, namely Sibu, \& Dalat of central Sarawak, and Bintulu \& Miri of northern region of Sarawak. The areas were reported to undergo different human activities in which Sibu site was timber harvesting site at Igan, Dalat site was sago plantation, Bintulu site was oil palm plantation and Miri site was the original forest (Loagan Bunut National Park). The geochemical properties of the areas reported by the researchers $[7,8,9,10,11]$ were compared and analysed. The correlation in between the geochemical properties of the peat soil and the land use/land activity is further discussed.

\section{Materials and Methods}

Peat soils originated from four different districts/region of Sarawak, namely Sibu, Dalat, Bintulu and Miri were reviewed in this paper. The peat soil samples were taken at $0-0.3 \mathrm{~m}$ depth at site by utilizing peat auger. The samples were dried up at $50^{\circ} \mathrm{c}$ and grinded to pass sieve aperture of $2 \mathrm{~mm}$ [12]. Four geochemical properties ( $\mathrm{pH}$, Total Carbon, Total Nitrogen, and Organic matter) and physical properties (bulk density) were analysed in this paper. The respective standard/ guidelines utilized were highlighted here. The $\mathrm{pH}$ test was determined by the method outlined in soil sampling and analysis handbook [13] while the soil organic matter and total carbon were analyzed by using loss on ignition method [14]. For the soil, the Total Nitrogen was determined by using the Kjeldahl method [15]. In a total soil nitrogen analysis a soil sample is first digested in Kjeldahl flask to convert all organic nitrogen into inorganic ammonium. Ammonia distillation was using concentrated sulfuric acid. Sodium or potassium hydroxide is using to increase the boiling point of the sulfuric acid. After that washing by using soap and water, amount of ammonium was calculated by difference. [16]

\section{Results and Discussion}

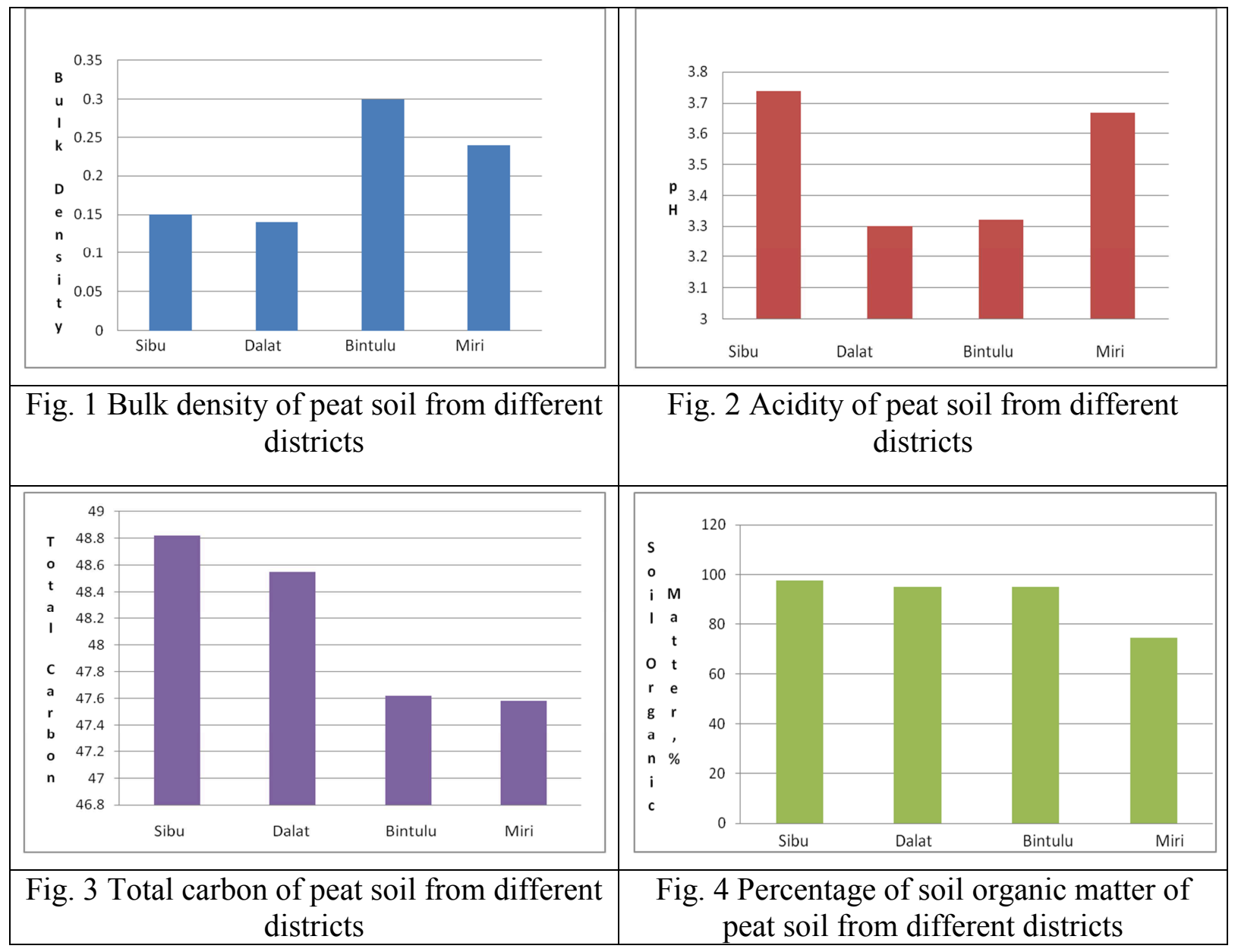




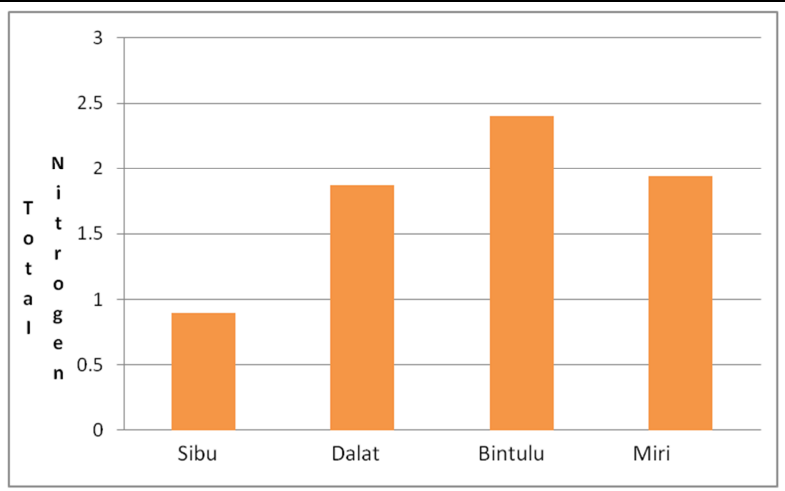

Fig. 5 Total nitrogen of peat soil from different districts

Fig. 1-5 summarized the mean comparison of the selected physical and geochemical properties of peat soil from different districts of Sarawak. The bulk density of peat soil from all the areas was low which range from 0.14 to $0.3 \mathrm{~g} / \mathrm{cm}^{3}$. The peat soils are categorized as acidity and the lowest $\mathrm{pH}$ was reported at Dalat site as 3.3. Overall, the results showed that total nitrogen of peat soil varies greatly while other properties remain quite constant.

It is reported that amount of the total carbon in the soil is related to its soil organic matter occupied in soil [17]. Based on the graphs, the total carbon of peat soil from different districts has not much different. The total carbon is found to fall in the range of $47 \%$ to $49 \%$. In terms of soil organic matter, peat soil from Miri was found to be the lowest which is $74.59 \%$ and coincidentally its total carbon is also reported to be the lowest in this case. The peat soil samples from Miri were originally from the Laogan Bunut National Park, which still remain undeveloped while other sites are developed [11]. Human activities such as timber harvesting and plantation will cut off the trees, branches and leaving it on the ground and decomposed [18]. Normally, the total carbon is reported to be correlated with the soil organic matter [19]. However, the total carbon of peat soil samples from Bintulu and Miri were not much different even though the organic matter contents were significantly different. Hence, it is believed that soil organic matter at the Bintulu site is not $100 \%$ contributed by the carbon content and should be also contributed by other minerals such as potassium, sodium. This is because the agricultural activities will normally associated with fertilizing [18]. Fertilizers will supply different minerals to the peat soil while Miri site is a natural forest and do not have any human activities at that area.

Higher contents of total nitrogen in secondary forest peat soil could be related to its genesis or the origin of the parent materials and the water management [19]. For the timber harvesting and plantation sites, the total nitrogen will be lower than the secondary forest because of initial land clearance, water table management, fertilizer application and liming. After the harvesting activities and land clearance activities, the water table decreased. This condition promotes more oxygen in the soil space and hence increases decomposition rate [14]. Laogan Bunut National Park is reported to be Padang Alan forest. The Padang Alan forest is reported to fibrous and much less decomposed peat, therefore is the most porous [21]. More porous will affect the water movement, therefore it will affect the total nitrogen in the peat soil.

\section{Conclusion}

Characteristics of the peat soil from different districts vary because of the human activities and its land use. Plantation and land clearance will give the effect to the peat soil. Furthermore, different types of the forest will also have different peat soil characteristic. 
Acknowledgements: The authors wish to gratefully acknowledge the financial support from Ministry of Higher Education (MOHE), Malaysia and Universiti Tun Hussein Onn Malaysia (UTHM) through FRGS Vot no. 1415.

\section{References}

[1] L., Melling, L. J. Uyo, K. J. Goh, R. Hatano and M. Osaki: Soils of Loagan Bunut National Park, Sarawak, Malaysia, Final Report. Peat Swamp Forest Project UNDP/GEF Funded. (2006).

[2] B.K, Bujang: Organic and peat soils engineering. Universiti Putra Malaysia, Press, ISBN 9832871-08-5, (2004).

[3] P.M., Jarret: Recent development in design and construction on peat and organic soils, In Proceedings of Recent Advances in Soft Soil Engineering,ed, Sarawak, p.1-30.

[4] L., Melling, Uyo, L. J., Goh K. J., M., Sayok, A. and Hatano, R.: Biophysical Characteristics of Tropical Peatland, Proceedings of the Soil Science Conference of Malaysia, Mukah, Sarawak. 17 19 April, (2007).

[5] E.F., Lambin, H.J. Geist and E. Lepers: Dynamics of land-use and land-cover change in the tropical, Annu. Rev. Environ. Resourc., (2003) 28:p. 205-241.

[6] A. J., William and Robert Horton: Soil Physics sixth edition, John Wiley and Son Isc., Hoboken, New Jersey, (2004).

[7] R., Empi, S.Gandaseca, H.A., Osemanu, and Nik Muhamad Ab. Majid: Comparison of selected Soil Chemical Properties of Two Different Mangrove Forests in Sarawak, American Journal of Environmental Sciences 6 (5), (2010) p. 438-441.

[8] E. S., Anto. S.Gandaseca, Osemanu.H.A, and Nik Muhamad Ab. Majid: Influence of Chemical Properties On Soil Carbon Storage of a Tropical Peat Swamp Forest, American Journal of Applied Sciences 6 (11): 1969-1972, (2009) ISSN 1546-9239.

[9] Masayuki kawahigashi and Hiroaki Sumida, Humus Composition and Physico-Chemical Properties of Humic Acids In Tropical Peat Soil Under Sago Palm Plantation, Soil Science and Plant Nutrition, (2006) p. 153-161

[10] Makilan Muniandy, Osumanu Haruna Ahmed, Nik Muhamad Ab. Majid and Mohd Khanif Yusop, Effects of Converting Secondary Forest to Oil Palm Plantation on Peat Soil Carbon and Nitrogen and other Soil Chemical Properties, American Journal of Environmental Sciences 5 (3), (2009) p. 406-412

[11] Alexander K Sayok, Abdul Rahim Nik, Lulie Melling, Rashid Abdul Samad1 and E.Efransjah, Some Characteristic of Peat inLoagan Bunut Natinal Park, Sarawak, Malaysia, Peat Swamp Forest Project UNDP/GEF Funded, Forest Research Institute Malaysia, (2002)

[12] Muhamad Ismawi Salimin, Seca Gandaseca, Osumanu Haruna Ahmed and Nik Muhamad Ab. Majid, Comparison of Selected Chemical Properties of Peat Swamp Soil Before and After Timber Harvesting, American Journal of Environmental Sciences 6 (2), (2010) p. 164-167.

[13] K.H., Tan: Soil Sampling Preparation and Analysis, 2nd Edn., Taylor and Francis, New York, (2005) p. 623. 
[14] K. Fiala, and J. Krhovjakova: Application of loss of ignition method to the soil organic carbon determination. Geophys. Res. Abstr., 10: 1-2, (2008).

[15] Jr., Jones, and J.B.: Laboratory Guide for Conducting Soil Tests and Plant Analysis, 1st Edn., CRC Press, USA, (2001) p. 384.

[16] R. C., Alfred: Influence Introduction to Soil Chemistry Analysis and Instrumentation, John Wiley and Son Isc., Hoboken, New Jersey, (2005) p. 120-122

[17] E.S., Anton, S. Gandaseca, O.H. Ahmed and N.M.A. Majid: Influence of chemical properties on soil carbon storage of a tropical peat swamp forest, Am, J. Applied Sci., 6: 1969-1972, (2009).

[18] N.C. Brady, and R.R. Weil: The Nature and Properties of Soils. 14th Edn., Pearson Education, Inc, New Jersey, (2008) p. 504-517.

[19] Y.L. Tie, and H.S. Kueh: A review of lowland organic soils of Sarawak, Department of Agriculture, Technical Paper 4, Research Branch, Sarawak, Malaysia,(1979).

[20] Y.L. Tie, and J.S. Lim: Characteristics and classification of organic soils in Malaysia, Proceedings of the International Symposium on Tropical Peatland, Malaysia Agricultural Research and Development Institute, Kuching, Sarawak, Malaysia,(1992).

[21] C.S., Teng: Keys to Soil Classification in Sarawak, Technical Paper 10, Soils Branch, Department of Agriculture Sarawak, (1993). 